\title{
The Effect of Service Quality in The Bhuana Artha Mulia Savings and Loan Cooperative on The Level of Member Satisfaction
}

\author{
I Gde Agung Wira Pertama ${ }^{1^{*}}$,I Gusti Ayu Ratih Permata Dewi \\ Universitas Warmadewa, Denpasar-Bali, Indonesia \\ \{rpdiga@gmail.com $\left.{ }^{1}\right\}$
}

\begin{abstract}
This study aims to analyze the effect of service quality on the Bhuana Arta Mulia Savings and Loan Cooperative on the level of member satisfaction. Service quality is measured using the dimensions of Service Quality namely Tangibles, Reliability, Responsiveness, Assurance and Empathy. The population in this study were customers of the Cooperative Savings and Loan Bhuana Arta Mulia with a total of 243 customers. Determination of sample size in this study uses the Slovin formula so that the total sample size is 70 customers. The data used are primary data. Primary data were obtained from a questionnaire distributed to members of the Bhuana ArtaMulia Savings and Loan Cooperative. The data analysis technique used is multiple linear regression analysis. The software used is SPSS. The results in this study are Tangible variables (X1), reliability variables (X2), responsiveness variables (X3), assurance variables (X4) and empathy variables (X5) affect the satisfaction of cooperative members.
\end{abstract}

Keywords: Service Quality; Member Satisfaction; Cooperatives

\section{Introduction}

The era of globalization at the time this led to competition in the banking sector is getting tight, the competition it can be physical or non- physical. Since the enactment of Law No. 7 Year 1992 concerning banking, showing progress in the banking sector in Indonesia experienced prospect that much better. Completion of the banking law foundation are also experienced by the Islamic banking who undergo the sustainable process. It is marked with the refinement of the rules of Islamic banking which is written in Law No. 2 Year 1998 concerning banking declared with obvious regarding the classification of activities of business the bank into two types, banks that perform conventional businesses activities and banks that conduct activities of a business based on the Islamic principles. Regulations that further strengthen the position of Islamic banks in doing activities of its business . In this case , Islamic banks have the power to carry out their activities, so that the position of Islamic banks with conventional banks is the same.

The number of banking institutions nowadays causing competition activities of business between institutions getting tighter. It are also experienced by the business entity, the competition that led to a situation that business entity should pay attention to strategy and carry out improvements in all fields so that the client still believes in the business entity are and still be on the market in a long term . Business entity trying to give the best service to the 
customers so that the customers satisfied, so they still become members and do not move to the other business entity. So with the large number of members without ruling out the quality of the business entity is the key to maintain the existence of a bank or business entity. One of the business entities that is the main topic of this study is the cooperatives .

Cooperatives is one of the business entity which has an important role in the economy . Cooperatives as one of the business entity was not able to avoid themselves from the competition [1]. As we know the competition between banking institutions is getting tighter that make cooperatives should strengthen the dimensions of quality of service so that the customer remains believed to cooperatives. Cooperatives act as the pillars of the Indonesian economy, and it is hoped that cooperatives can compete with other business entities, improve the community's economy and be able to reduce economic inequality. To achieve the objectives mentioned, cooperative perform various activities of the business are beneficial to its members . Based on the various types of demands so the cooperative have many form and types according to the surrounding conditions. One type of cooperation that exist and thrive in society, namely the Cooperative Savings and Loan. Judging from the name Cooperative Savings and Loan engaged in the field of services of finance. In the financial services sector, cooperatives act as recipients and distributors of funds for their members [2]. As a receiver, the cooperative received a deposit required as well as the savings voluntarily from members of them, while as distributors, cooperatives lend money to members with some conditions or requirements that apply in the cooperative.

The indicators of major in the development of cooperatives such as: member, institution, volume of business, capital, chance of employment, assets, financing and service . Purpose of the cooperative that is the institution that legal entity that would like to promote the economy of the people. Cooperative is an organization belonging together which members nor the managers . Cooperatives aim for the welfare of its members. While operating the cooperative will be associated with servicing services . Member satisfaction is an added value in cooperative institutions in increasing economic turnover and adding members . All of it depends on the quality of service that will be given to members, employees who can be reliable by members will be included in the ratings member that the increase in quality of service. Customers satisfaction the level where the notion of performance (percieved performance) of products in accordance with the expectations of the perceived customer [3] . If the performance of the product is much lower than the expectations of the customer, then the customer is not going to be satisfied. Conversely, if the performance is in accordance with expectations or exceeds expectations, then the customer will be satisfied. Customer satisfaction is determined by the non-conformance of hope, which is a comparison between the performance of which is felt with expectations. Member / customer is an asset that is most valuable in the service sector as well as the business sector, to make the organization or business running well. Satisfaction of a member can be seen from the loyalty of the members, because the more service we give to the member, they will be getting close to us . This research was conducted at the Bhuana Arta Mulia Savings and Loan Cooperative . Bhuana Arta Mulia Savings and Loan Cooperative is one of the cooperative institutions in Nusa Dua which was founded on January 9, 2008 on Jl. Dharmawangsa No. 45 Kampial Nusa Dua . Selection of research at the Cooperative Store Credit Bhuana Arta Mulia because it has large number of members that were pretty much evident with the increase in the number of members of the cooperative each year that researchers want to know the quality of service that is influential on the level of satisfaction of members of the cooperative. Increasing member satisfaction in the long term can help change the economy and sustain the economy, especially at the Bhuana Arta Mulia Savings and Loan Cooperative. Therefore, researchers are 
interested to do research on the quality of service that is provided by the institution of cooperatives, with the title " The Effect of Service Quality in The Bhuana Artha Mulia Savings and Loan Cooperative on The Level of Member Satisfaction ". The formulation of the problem to be analyzed in the research this is How Quality of Services In The Bhuana Artha Mulia Savings and Loan Cooperative Influences the Member Satisfaction Level?

\section{Literature Review}

\subsection{Consumer Behavior Theory}

The behavior of consumers is an act of consumers in terms of searching for, swapping, use, assess , regulate goods or services that they perceive will satisfy the needs of them. In another sense that is, how consumers want to give their limited source such as money, time , effort to get / redeem the goods or services that he wants. Analysis of the various factors that have an impact on consumer behavior is the basis for developing a marketing strategy . For this reason, marketers must understand consumers, like what they needed, what they desire , and how consumers make decisions .

Consumers behavior as actions that directly involved in getting, consume and spent products and services, including the decisions that precede and follow the actions of this [4] .

Consumers behavior is the study of how individuals, groups, and organizations select, buy , use , and positioning of goods, services, ideas, or experiences to satisfy the needs and desires [5].

This can be concluded that the behavior of consumers is all the actions, activities, as well as the process of psychological which encourage action that at the time before buy, when to buy , use, spent products and services after doing things at the top or activities evaluated.

\subsection{Cooperative}

Cooperatives are a form of enterprise that was founded by particular people, to carry out the activities of certain, based on the provisions and objectives of certain well [6] . According to Law No. 25 Year 1992, " Cooperative is an business entity which consists of those to individual or entity laws cooperative with bases its activities based on the principle of cooperative once the movement of the economy of the people who, based on the principle of kinship ". Cooperative is an association of people, usually who has limited source of economy which through a form of organization of the company are monitored in a democratic, each giving donations are equivalent to the capital required, and are willing to bear the risks and receive the rewards that correspond to the business that they do [6]. In general cooperative understood as an association of people who have a goal and are voluntarily come together to fight for the purpose of the same is prospering economy. So, of some sense that may we conclude that a cooperative is an association of people who have needs together in a voluntary , using the principle of kinship. Has a goal for the welfare of members in particular and the society in general.

\subsection{Service Quality Measures}

The quality of service is measured by using a dimension SERVQUAL (Service Quality.) Dimensions of SERVQUAL are namely :

1. Tangibles, ability of a company to show its existence to external parties. Appearance and capability of facilities and physical infrastructure as well as the environment it is 
a tangible proof of service that is given by the services provider. Which includes the physical infrastructure ( buildings, warehouses and so forth ), fixtures and equipment are used ( technology ) as well as the appearance of its employees .

2. Reliability is ability of companies to provide services that were promised are accurate and reliable .

3. Responsiveness is a will to assist and provide services that quickly and precisely to the customer, with delivery of clear information.

4. Assurance that knowledge, politeness, and the ability of the employees of the company to foster a sense of trust of the customers.

5. Empathy, which provides care that is sincere and is personally which is given to the customers to attempt to understand the wishes and needs of the customers .

\subsection{Hypothesis \\ Influence Tangible with Against Satisfaction Members}

Because a form of service is not able to be seen, not to smelled and not be touched, so the aspects of physical manifestation becomes important as the size of the service . Customers will use the senses of vision for assessing a quality of their services . Physical form (tangible) is the need of customers who focus on the facilities physical such as buildings and rooms , provided a place of parking, cleanliness, neatness and comfort rooms, completeness equipment, means of communication as well as the appearance of employees [7] . Evidence physical that both will affect the perception of the customer. At the moment that is the same aspect of it also is one of the sources that influence the expectations of the customers . Because the evidence physical that both the expectations of consumers become higher . Therefore it is important for companies to know how far aspects of manifestation physically the most appropriate, which still gives the impression positively on the quality of service that is given but does not lead to the expectations of customers are too high to be able to meet the needs of consumers and give satisfaction to the consumer. The attributes that exist in the dimension of this is the modern tools and attractive facilities. Relationships between physical form and the consumers satisfaction have positive influence on the consumers satisfaction [8] . The better consumers perception towards physical forms then the consumers satisfaction also will be increased significantly. And if the consumers perception towards physical forms is bad then consumers satisfaction also will be getting lower . Research that is done by [9] states that the variable compliance, assurance, tangibles, reliability, responsiveness, empathy influence positively and significantly to the customers satisfaction. On the basis of the description above, it can be presented hypothesis is as follows.

H1: Tangible has a positive effect on member satisfaction.

\section{Influence of Reliability of Member Satisfaction}

Reliability is the ability of the company to provide the service after with what the promises are accurate and reliable [10]. Performance should be in accordance with the expectations of customers which means the accuracy of the time, the service that is the same for all customers without error, an attitude that is sympathetic, and the accuracy of which is high . Fulfillment of promises in service will reflect the company's credibility . Reliability is the fulfillment of the promise of service immediately and satisfactorily of companies [7] . Attributes - attributes that are in the dimension of this among others is give services according appointments , accountability concerning the handling of consumers will be the problem of service, provide the service which is good when the impression the first to consumers, and do not distinguish 
one with the other, provide services right time, provide information to consumers about when the promised services will be realized [8] .

Relationship between reliability and the customers satisfaction is give posive influence to the consumers satisfaction. The more and better consumer perception against the reliability of the company, customers satisfaction also will be increased significantly. And if the perception of consumers about the reliability worse then the customers satisfaction also will be getting lower . Research that is done by [9] states that the variable compliance, assurance, tangibles, reliability, responsiveness, empathy influence positively and significantly to the satisfaction . On the basis of the description above, it can be presented hypothesis is as follows :

$\mathrm{H} 2$ : Reliability has a positive effect on member satisfaction .

\section{Influence Responsiveness of Member Satisfaction}

Responsiveness is the response or readiness of employees to assist customers and provide service that is fast and responsive, which includes the alertness of employees in serving customers, the speed of the employees in the handling of transactions as well as the handling of complaints of customers . Responsiveness is a policy to assist and provide services that quickly and precisely to the customer, with delivery of clear information. Keep consumers waiting will lead to negative perception in the quality of service [10]. Based on many studies are done, there is one thing that often makes the customer is disappointed, that make customer asking back and forth when in need of information. From one staff passed to another staff and do not know or answered clearly what that is desired by the customer . Really bad services are not responsive and definitely will make the customer feel not satisfied Companies that give a good responsiveness will increase the satisfaction that is felt by the consumer. While attributes - attributes that exist in the dimension of this is give a fast and responsive service, willingness to help or assist the consumer, ready and responsive to handle the response demand of the consumers [8] .

Relationships between responsiveness and the consumers satisfaction is responsiveness has influence positively to the consumers satisfaction. The more and better perception of consumers to company responsiveness, the consumers satisfaction also will be increased significantly. And if the perception of consumers to responsiveness is bad, then the consumers satisfaction also will be getting lower. Research that is done by [9] states that the variable compliance, assurance, tangibles, reliability, responsiveness, empathy influence positively and significantly to the consumers satisfaction. On the basis of the description above, it can be presented hypothesis is as follows :

H3: Responsiveness has a positive effect on member satisfaction .

\section{Influence Assurance Against Member Satisfaction}

Assurance which includes the ability of employees on knowledge of the product is precisely, hospitality, attention and courtesy, the ability to provide information, the ability to provide security to take advantage of the services that are offered and the ability to instill the confidence of customers to the company, the nature can be trusted that owned the staff, free from danger, risk or any doubt [10]. Knowledge, politeness and the employees skills of the company can foster a sense of trust of the customers to the company. The attributes that exist in the dimension of this is employees who gave guarantees in the form of trust themselves to consumers, making consumers feel safe when using the services of service companies, employees are polite, employees who have knowledge of the area so it can answer questions from consumers [8] . 
Warranty (assurancce) which covers the knowledge and skills of the employees in serving the needs of customers, the ethics of the employees, and guarantee the security of the company's top customers when transacting. The existence of guarantees of security of a company will make customers feel safe and without no sense of hesitation to do the transaction. Besides the assurance of a company bank will affect the satisfaction of consumers for what are desirable customers can be met by the company that is with the knowledge and skills of the employees are . Courtesy and friendliness of the employees will make the customer feel valued so that they are satisfied with the service that was given by the company . Relationship between guarantee and the consumers satisfaction is the guarantee of having influence positively to the consumers satisfaction. The more and better perception of consumers to guarantee that is given by the company the consumers satisfaction also will be increased significantly. And if the perception of consumers to guarantee that given by company bad the satisfaction of consumers also will be getting lower. Research that is done by [9] states that the variable compliance, assurance, tangibles, reliability, responsiveness, empathy influence positively and significantly to the consumers satisfaction. On the basis of the description above, it can be presented hypothesis is as follows :

H4: Assurance has a positive effect on member satisfaction.

\section{Influence Emphaty Against Satisfaction Member}

Empathy that concern by giving an attitude that is sincere and private that given the company to customers like the ease of contacting the company, the employees ability to communicate with customers and business companies to understand the customers needs and desire [10] . A company is expected to have the ability to understand and knowledge of customer, understand the needs of customers in specific, and have operational time that is convenient for the customer. From explanations above can be concluded that concern is attention to particular or individual against all the needs and complaints of customers, and the communication were better among employees with customers. With special attention and good communications from an employee of a bank on the customer will affect also the satisfaction of the customer, because the customer will feel noticed by the company, namely what are needed and complained addressed as well by the company. The attributes that exist in the dimension of this is giving attention of the individual to the consumer, the employee who understands the wishes of the consumers [8] .

Relationships between concern with the consumers satisfaction is a concern to have influence positively on the consumers satisfaction. More and better perception of consumers towards care that is given by the company the satisfaction of consumers also will be increased . And if the perception of consumers to concern that given by company bad the satisfaction of consumers also will be getting lower. Research that is done by [9] states that the variable compliance, assurance, tangibles, reliability, responsiveness, empathy influence positively and significantly to the satisfaction of the customer. On the basis of the description above, it can be presented hypothesis is as follows :

H 5: Emphaty has a positive effect on member satisfaction

\section{Methods}

The research location was chosen at the Bhuana Arta Mulia Savings and Loan Cooperative. The population in this study were customers of the Bhuana Arta Mulia Savings 
and Loan Cooperative with a total of 243 customers . Determination of the sample size in this study using the opinion of Taro Yamane or Slovin because the population is more than 100 so that the determination of the sample size can be taken between $10 \%-15 \%$ or $20 \%-25 \%$. The formula that is used is

$\mathrm{n}=\underline{243}$

$1+\overline{243}(0.1)^{2}$

$\mathrm{n}=70$ samples

The method that is used for the collection of data in research this is by questionnaire or questionnaires . Technical analysis of the data used is analysis of regression linear multiple .

\section{Results and Discussion}

\subsection{Research Instrument Testing}

Testing of the instrument of research carried out by using test validity and reliability . Before you do the research, instrument study tested first in advance with the goal to determine the validity of the instrument of research that . Experiments conducted on 70 respondents who have characteristics similar to the respondents who became the sample in the study of this. The results of the testing indicate instrument research has valid and reliable.

\subsection{Descriptive Statistics}

This study used six research variables, consisting of 5 independent variables and 1 dependent variable. Where the independent variables in this study are Tangible (X1), Reliability (X2), Responsiveness (X3), Assurance (X4) and Emphaty ( X5). While the dependent variable or dependent variable is customer satisfaction (Y). Data from the six variables are obtained by using a questionnaire. The variable descriptions in this study include :

Table 1. Descriptive Statistics

\begin{tabular}{lll|l|l|l}
\hline & N & Minimum & Maximum & Mean & Std. Deviation \\
\hline X1 & 70 & 3,00 & 11,04 & 9,0920 & 2,81277 \\
\hline X2 & 70 & 3,00 & 12,15 & 9,6114 & 2,58089 \\
\hline X3 & 70 & 3,00 & 11,47 & 9,2620 & 2,60268 \\
\hline X4 & 70 & 3,00 & 10,93 & 8,8917 & 2,79837 \\
\hline X5 & 70 & 3,00 & 11,32 & 9,3637 & 2,79539 \\
\hline Y & 70 & 4,32 & 11,56 & 9,0803 & 2,49730 \\
\hline Valid N (listwise) & 70 & & & & \\
\hline
\end{tabular}

Source : Processed data, 2020 .

\subsection{Classic Assumption Test}

Testing the assumptions of classical is used to determine whether the model regression were used feasible to predict the loyalty of consumers based on input variables independent. Based on the test assumptions classic that made the model regression is already feasible to be used.

\subsection{Results Analysis Regression Regression}


To determine the influence of factors of satisfaction which consists of tangible (X1), reliability (X2), responsiveness (X3), assurance (X4) and empathy (X5) to the satisfaction of the customer $(\mathrm{Y})$ by using analysis regression linear multiple. The results of the calculation of multiple linear regression are as follows.

Table 2. Results of Analysis Regression Regression

\begin{tabular}{llll}
\hline Variabel & $\begin{array}{l}\text { Koefesien } \\
\text { Regresi (B) }\end{array}$ & t & Sig. \\
\hline X1 & 0,209 & 2,861 &, 006 \\
X2 & 0,221 & 3,039 &, 003 \\
X3 & 0,246 & 3,103 &, 003 \\
X4 & 0,165 & 2,271 &, 027 \\
X5 & 0,160 & 2,114 &, 038 \\
\hline Konstanta & $-0,194$ & & \\
Adjusted R Square & 0,782 & \\
F Hitung & 50,615 & & \\
Signifikansi F & 0,000 & & \\
Source : Processed data, 20 20 & & &
\end{tabular}

Based on the table V.16 mentioned in the above obtained equation as follows :

$\mathrm{Y}=-0.194+0.209 \mathrm{X} 1+0.221 \mathrm{X} 2+0.246 \mathrm{X} 3+0.165 \mathrm{X} 4+0.160 \mathrm{X} 5$

Based on the above equation, the tangible variable ( physical evidence service ) has a regression coefficient of 0.209 and is significant. It is means variable tangible ( service evidence of physical ) has the effect of which is positive towards the satisfaction of customers which is reflected in the Bhuana Arta Mulia Savings and Loan Cooperative in part custumer service (CS) has a completeness office modern (Unit of computer, telephone, machine count, online terminals, tools detection of money, currency etc.), room Bhuana Arta Mulia Savings and Loan Cooperative has facilities physically that is attractive to customers ( chairs, tables guests, TV, information, monitoring, etc.).

The variable reliability (X2) has a regression coefficient of 0.221 and has a significant effect . It is meant variable reliability (service reliability) has the effect of which is positive towards the satisfaction of customers which is reflected in the Bhuana Arta Mulia Savings and Loan Cooperative airport right time, Bhuana Arta Mulia Savings and Loan Cooperative in serving customers without error and Bhuana Arta Mulia Savings and Loan Cooperative provides guidance on excellence of products that are offered by the Bhuana Arta Mulia Savings and Loan Cooperative.

The responsiveness variable (X3) has a regression coefficient of 0.246 and has a significant effect. It 's means that the variable responsiveness ( service response) has the effect of which is positive towards the satisfaction of customers which is reflected in the Bhuana Arta Mulia Savings and Loan Cooperative friendly and communicative in serving customers , Bhuana Arta Mulia Savings and Loan Cooperative DIY deal with problems that presented customers with fast and Bhuana Arta Mulia Savings and Loan Cooperative always prepares the administration and funds needed by customers .

The assurance variable (X4) has a regression coefficient of 0.165 and has a significant effect . It is meant variable assurance ( service assurance ) has the effect of which is positive towards the satisfaction of customers . 
The emphaty variable ( empathy service ) (X5) has a regression coefficient of 0.160 and has a significant effect. It is meant variable empathy ( service empathy ) has the effect of which is positive towards the satisfaction of customers .

Based on table V.16, it is also obtained the calculated $F$ value of 50.615 with a sig value of 0.000 . It is meant factors tangible (X1), reliability (X2), responsiveness (X3), assurance (X4) and empathy (X5) effect significant on customer satisfaction (Y).

Meanwhile, the adjusted $r$ square value of 0.782 means $78.2 \%$ of the customer satisfaction variable of the Bhuana Arta Mulia Savings and Loan Cooperative is influenced by the five services quality, which consists of tangible service quality, reliability, responsiveness, assurance and emphaty.

Based on the results of the analysis on the above, the variable independent which consist of quality of service tangible, reliability, responsiveness, assurance and empathy influence significantly to the satisfaction of customers Bhuana Arta Mulia Savings and Loan Cooperative as indicated by the sig $\mathrm{F}$ value of $0.000<0.05$.

As it is known, the success of a company lies not only in the number of customers the company gets, but also how to maintain them so that these customers remain loyal to the company and do not want to move to other companies. In the middle of the competition businesses are increasingly tight, retain customers is one step that is appropriate in order to keep survive in the competition are .

To retain customers in order to remain satisfied of the quality of service to the company, the company must maintain the consumers satisfaction on the quality of service that is given company. The flavors are satisfied and not satisfied the customer is located on the relationship between the expectations of customers with a reality that is given by the product / service it . If the reality is more substantial than the expectations of customers, then customers will feel satisfied, on the contrary, if the fact that accepted customer does not like what is expected so customers are going to feel not satisfied .

If customers feel satisfied with the quality of service that is given, then the customers are going to come back to use the products / services that , on the contrary, if the customer was not satisfied with the quality of service which granted the company then the consumer not going to come back, even going to switch to products / services in place another.

\subsection{Influence Tangible with Against Members Satisfaction}

Because a form of service is not able to be seen, not to smelled and not be touched so the aspects of manifestation of physical becomes important as the size of the service . Customers will use the senses of vision for assessing a quality of their services . Physical form (tangible) is the need of customers who focus on the facilities physical such as buildings and rooms, provided a place of parking, cleanliness, neatness and comfort rooms, completeness equipment, means of communication as well as the appearance of employees [7]. Evidence physical that both will affect the perception of the customer. At the moment that is the same aspect of it also is one of the sources that influence the expectations of the customers . Because the evidence physical that both the expectations of consumers become higher . Because it is a thing that is important for companies to know how far aspects of manifestation physically the most appropriate, which still gives the impression positively on the quality of service that is given but does not lead to the expectations of customers are too high to be able to meet the needs of consumers and give satisfaction to the consumer. The attributes that exist in the dimension of this is the modern tools and attractive facilities . Relationships between physical form and the consumers satisfaction is a physical form have influence positively on the consumers satisfaction [8]. The more and better perception of consumers towards a form 
of physical then the satisfaction of consumers also will be increased significantly . And if the perception of consumers towards a form of physical bad then the satisfaction of consumers also will be getting lower . Research that is done by [9] states that the variable compliance, assurance, tangibles, reliability, responsiveness, empathy influence positively and significantly to the consumers satisfaction.

\subsection{Influence of Reliability Of Satisfaction Member}

Reliability is the ability of the company to provide the service after with what the promises are accurate and reliable [10] . Performance should be in accordance with the expectations of customers which means the accuracy of the time, the service that is the same for all customers without error, an attitude that is sympathetic, and the accuracy of which is high . Fulfillment of promises in service will reflect the company's credibility . Reliability is the fulfillment of the promise of service immediately and satisfactorily of companies [7] . Attributes - attributes that are in the dimension of this among others is m emberikan services according appointments, accountability concerning the handling of consumers will be the problem of service, provide the service which is good when the impression the first to consumers, and do not distinguish one with the other, provide services right time, provide information to consumers about when the promised services will be realized [8] . Relations reliability to the satisfaction of customers is reliability have influence positively to the satisfaction of consumers . More and better perception of the consumer against the reliability of the company the satisfaction of consumers also will be increasingly high. And if the perception of consumers about the reliability worse then the satisfaction of consumers also will be getting lower . Research that is done by [9] states that the variable compliance, assurance, tangibles, reliability, responsiveness, empathy influence positively and significantly to the satisfaction .

\subsection{Influence Responsiveness Of Satisfaction Member}

Responsiveness is the response or readiness of employees to assist customers and provide service that is fast and responsive, which includes the alertness of employees in serving customers, the speed of the employees in the handling of transactions as well as the handling of complaints of customers . Responsiveness is a policy to assist and provide services that quickly and precisely to the customer, with delivery of clear information. Keep consumers waiting will lead to negative perception in the quality of service [10] . Based on many studies are done, there is one thing that often makes the customer is disappointed, that make customer asking back and forth when in need of information. From one staff passed to another staff and do not know or answered clearly what that is desired by the customer . Really bad services are not responsive and definitely will make the customer feel not satisfied . Companies that give a good responsiveness will increase the satisfaction that is felt by the consumer . While attributes - attributes that exist in the dimension of this is give a fast and responsive service, willingness to help or assist the consumer, ready and responsive to handle the response demand of the consumers [8] .

Relationships between responsiveness and the consumers satisfaction is responsiveness has influence positively to the consumers satisfaction. The more and better perception of consumers to company responsiveness, the consumers satisfaction also will be increased significantly. And if the perception of consumers to responsiveness is bad, then the consumers satisfaction also will be getting lower . Research that is done by [9] states that the variable compliance, assurance, tangibles, reliability, responsiveness, empathy influence positively and significantly to the consumers satisfaction. 


\subsection{Influence Assurance Against Satisfaction Member}

Assurance which includes the ability of employees on knowledge of the product is precisely, hospitality, attention and courtesy, the ability to provide information, the ability to provide security to take advantage of the services that are offered and the ability to instill the confidence of customers to the company, the nature can be trusted that owned the staff, free from danger, risk or any doubt [10] . Knowledge, politeness and the employees skills of the company can foster a sense of trust of the customers to the company. The attributes that exist in the dimension of this is employees who gave guarantees in the form of trust themselves to consumers, making consumers feel safe when using the services of service companies, employees are polite, employees who have knowledge of the area so it can answer questions from consumers [8] .

Warranty (assurancce) which covers the knowledge and skills of the employees in serving the needs of customers, the ethics of the employees, and guarantee the security of the company's top customers when transacting. The existence of guarantees of security of a company will make customers feel safe and without no sense of hesitation to do the transaction. Besides the assurance of a company bank will affect the satisfaction of consumers for what are desirable customers can be met by the company that is with the knowledge and skills of the employees are . Courtesy and friendliness of the employees will make the customer feel valued so that they are satisfied with the service that was given by the company . Relationship between guarantee and the consumers satisfaction is the guarantee of having influence positively to the consumers satisfaction.

The more and better perception of consumers to guarantee that is given by the company the consumers satisfaction also will be increased significantly . And if the perception of consumers to guarantee that given by company bad the satisfaction of consumers also will be getting lower . Research that is done by [9] states that the variable compliance, assurance, tangibles, reliability, responsiveness, empathy influence positively and significantly to the consumers satisfaction.

\subsection{Influence Emphaty Against Satisfaction Member}

Empathy that concern by giving an attitude that is sincere and private that given the company to customers like the ease of contacting the company, the employees ability to communicate with customers and business companies to understand the customers needs and desire [10] . A company is expected to have the ability to understand and knowledge of customer, understand the needs of customers in specific, and have operational time that is convenient for the customer. From explanations above can be concluded that concern is attention to particular or individual against all the needs and complaints of customers, and the communication were better among employees with customers. With special attention and good communications from an employee of a bank on the customer will affect also the satisfaction of the customer, because the customer will feel noticed by the company, namely what are needed and complained addressed as well by the company. The attributes that exist in the dimension of this is giving attention of the individual to the consumer, the employee who understands the wishes of the consumers [8] .

Relationships between concern with the consumers satisfaction is a concern to have influence positively on the consumers satisfaction. More and better perception of consumers towards care that is given by the company the satisfaction of consumers also will be increased . And if the perception of consumers to concern that given by company bad the satisfaction of consumers also will be getting lower . Research that is done by [9] states that the variable 
compliance, assurance, tangibles, reliability, responsiveness, empathy influence positively and significantly to the satisfaction of the customer

\section{Conclusions}

Based on the analyzes were performed on a chapter previously , the conclusion that can be drawn in the study of this is variable Tangible (X1), variable reliability (X2), the variable responsiveness (X3), variable assurance (X4) and variable empathy (X5) effect on the satisfaction of members. As for some suggestions in research, namely:

Customers satisfaction in terms of quality of service is not only influenced by the tangible, reliability, responsiveness, assurance and empathy, will however still many factors other are not used in this study which can affect customer satisfaction .

This study is only limited to using 70 savings customers who are taken as the sample in the study . Research further expected to use over many samples of research that can represent the population as a whole.

\section{References}

[1] Suhartono, "Gait Cooperative in Facing Free Trade," Scientific Journal Among Makarti, vol. 2, no.4, 2009.

[2] Cashmere, "Banks and Other Financial Institutions," Jakarta: Rajawali Press, 2013

[3] P. Kotler, and G. Armstrong, "Principles of Marketing," Jakarta: Erlangga, 2001

[4] J. Engel, D. Roger, Blackwell and P. W. Miniard, "Consumer Behavior Rather languages: Budyanto," Jakarta: Binarupa Aksara Publisher, 2008

[5] P. Kotler, "Marketing Management," Jakarta: PT. Gramedia Group Index, 2005

[6] R. Baswir, "Indonesian Cooperative," Yogyakarta: BPFE, 2000

[7] V. A. Zeithaml, M. J. Bitner, "Service Marketing," New Jersey: The McGraw Hill Companies Inc, 1996

[8] Abdillah and Ramdan, "Relationship Characteristics of Patients With Satisfaction Patients Outpatient In Puskesmas Sindangkerta Regency Bandung Barat", 2008

[9] Hasan, "Effect of Quality Services Islamic Bank Of Satisfaction Customer in Bank Muamalat Indonesia Semarang branch," Journal of Economics and Business, vol. 1, no. 1 , pp. $1-14,2006$

[10] A. Parasuraman, A. Z. Valerie, and L. L. Berry, "SERVQUAL: A Multiple Item Scale For Measuring Consumer Perception Of Service Quality," Journal Of Retailing, vol. 64, no. 1, pp 12-37, 1998 